\title{
WHERE DID GENERAL MOTORS GO WRONG WITH THE IGNITION SWITCH RECALL?
}

\author{
Adnan ShaOut and Cassandra Dusute \\ Electrical and Computer Engineering Department, The University of Michigan - Dearbon \\ Dearbon, MI 48128, USA. \\ shaout@umich.educdusute@umich.edu
}

\begin{abstract}
When it comes to purchasing a new car, a buyer expects the car to be safe and reliable. It is the responsibility of the automaker to ensure that those expectations are met. However, to err is human; recalls are a necessary part of life. When a recall happens, it then becomes the responsibility of the automaker to issue the recall in a timely manner. However, that was not the case with the General Motors (GM) ignition switch recall. The focus of this paper will be on the GM ignition switch, including sections regarding the problem with the switch, who may have been responsible for approving the switch, and possible suggestions on how GM could have prevented the recall.
\end{abstract}

ABSTRAK: Ketika keputusan diambil untuk membeli kereta baru, pembeli mahukan kereta yang selamat dan berwibawa. Adalah menjadi kewajipan pembuat kereta tersebut untuk memastikan bahawa harapan tersebut tercapai. Namun, kita hanyalah manusia; penarikan balik menjadi kemestian. Apabila berlakunya perihal menarik balik produk, ianya adalah tanggungjawab pembuat kereta untuk menariknya dengan cara yang sepatutnya. Namun dalam kes tarik balik suis pencucuh General Motors (GM) ini tidak berlaku. Kertas kerja ini akan memfokuskan kepada suis pencucuh GM; termasuklah masalah suis, pihak yang bertanggungjawab meluluskannya dan beberapa cadangan bagaimana sepatutnya GM boleh menghalang isu penarikan balik ini.

KEYWORDS: approval process; validation plan; performance testing; ignition switch; embedded system; torque requirements; automotive recalls; industry

\section{INTRODUCTION}

The look and feel of a luxury sports car without the cost - this concept is one that automakers dream of fulfilling not only automakers, but people in general. Who doesn't want a car that compares easily to a luxury model at a tenth of the cost? We don't realize that the difference in cost comes at a price of its own. For example, the difference in cost may come from using cheaper materials. Sometimes, the difference in cost shows itself in the "convenience" issues - you know, those annoying little quirks that are ignored because they don't affect how the car runs - that weren't important enough to fix.

But what classifies an issue as a convenience issue over safety? In most cases, they are apparent: something wrong with the materials or how something looks. Other times, they are a little more difficult to diagnose, like a too easy to turn ignition. These issues are the ones that need the most attention since they can turn from a convenience issue to a safety issue in no time. Take, for example, the GM ignition switch. It started by being classified as convenience issues while it was, in reality, a safety issue. Lack of attention and understanding will prove to be the cause of that, as will be discovered in this paper. This paper is organized as follows: section 2 will focus on the recent General Motor 
recalls which were centered on the faulty ignition switch. The ignition switch will be explained. Section 3 will present the main problem surrounding the switch which will be defined. Section 4 will comment on who should be responsible for the ignition switch. Section 5 will present possible solutions to the problem. Section 6 will finally conclude the paper.

\section{IGNITION SWITCH}

The GM ignition switch that is at the center of their current recall was originally built with the ease of use in mind. GM had received multiple complaints that their ignition switches from previous years were too hard to turn. In an attempt to make it seem like the driver was in a European sports car, the early 2000 models would have an ignition switch that was easier to turn. Figure 1 shows a diagram of the complete ignition module, highlighting the three main parts that were affected by the recent recall [1-3]. GM didn't realize that the decrease in the torque required increased the chances of the vehicle's power mode turning out of Run into Accessory while the vehicle was on the road.

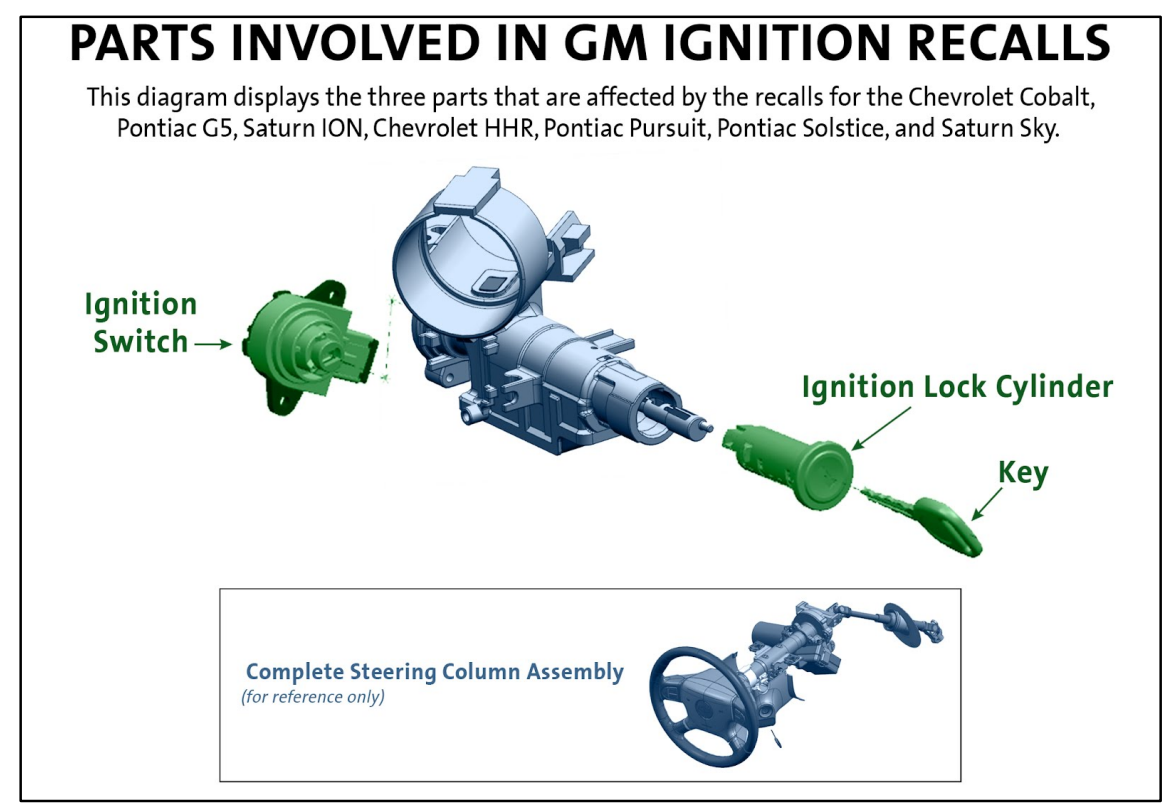

Fig. 1: Diagram of automotive ignition housing affected by recall.

\subsection{Requirements}

GM had specific requirements for the ignition switch, some which can be seen in Figures 2 and 3, respectively. Through the many reports filed against the ignition switch, it seems that there are two main issues that were addressed in the initial requirements document. Those are the torque required and the vibration environment.

a) Torque: One of the major issues surrounding the ignition switch was that the torque did not meet initial requirements. The torque - or force necessary to turn an object around an axis- required for the ignition switch should have been between 10 and $20 \mathrm{~N} \cdot \mathrm{cm}$ (Newton centimeters). In reality, it was consistently less than $10 \mathrm{~N} \cdot \mathrm{cm}$.

Why is torque important? The torque of the ignition switch, along with detents devices used to hold the switch in place - help to make sure that the ignition switch does not move unless it is intentional. With the torque being lower than what was required, it 
was easier to accidently turn the switch to another state, for example from Run to Accessory.

b) Vibration: another issue with the switch is that it could turn from Run to Accessory during extreme moments of vibration. The specification document describes how the ignition should act when a vehicle is in a high-vibrating environment. Figure 3 shows these requirements. Vibration tests were not listed under the part's performance test section, and the results for these tests do not appear in the Validation Report. However, they are recorded as validation tests within the specifications document, and it states that these tests are run independently.

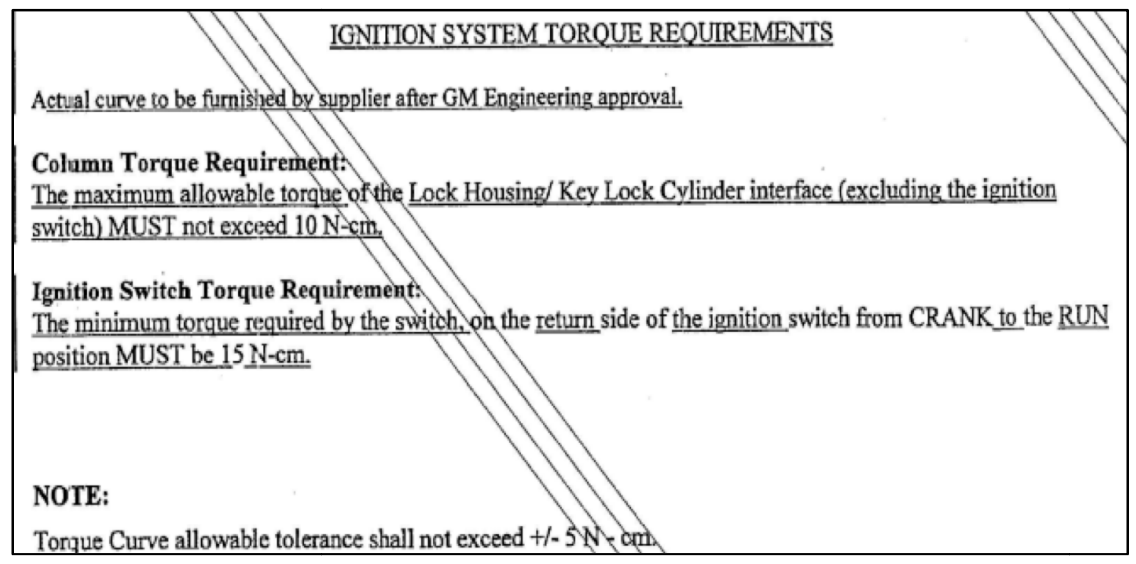

Fig. 2: GM ignition switch torque requirements [4-6].

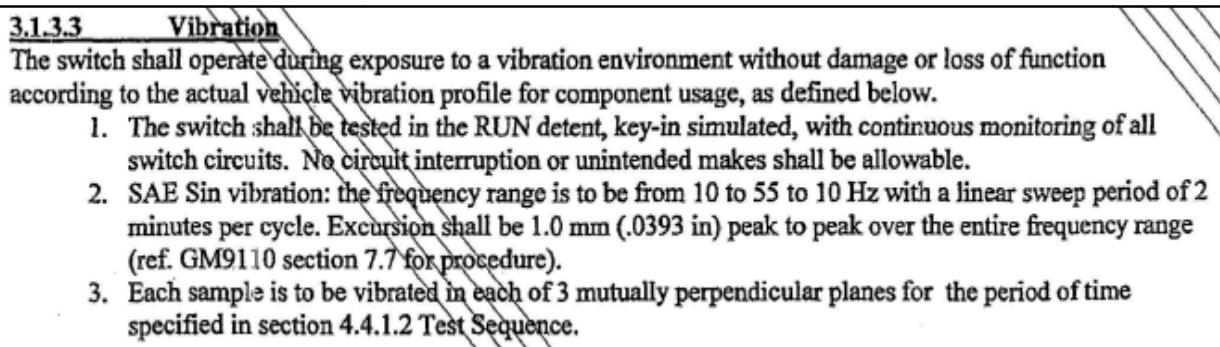

3. Each sample is to be vibrated in each of 3 mutually perpendicular planes for the period of time specified in section 4.4.1.2 Test Sequence.

Fig. 3: GM ignition switch vibration requirements [6].

Vibration added with decreased torque and any heavy object on a key chain could also result in the vehicle's ignition switch turning from Run to Accessory without the intent of the driver. The ignition switch for the recalled vehicles was also designedto remove power from the vehicle's airbags whenever it was in off or accessory modes. This was to prevent the driver and any passengers from getting injured by the airbags in the event an accident occurred while the vehiclewas parked. This was a deliberate and known design from GM which engineers on the project should have been familiar with.

The two lacking requirements combinedwith the previous design are the cause of multiple accidents - some fatal - during the last decade. The common scenario seems to go as follows:

- Vehicle is in Run.

- Ignition is turned from Run to Accessory, either by contact from driver or vehicle is on a bumpy road with a heavy keychain. This state change turns off power to airbags, power steering and power brakes, making the vehicle harder to control. 
- Engine stalls because it is no longer in Run.

- In the case of an accident, the driver and any passengers are left without the safety of airbags, and are unable to steer or brake with ease. At high-speeds, this has been known to be fatal.

In normal situations, when a vehicle's engine stalls, the vehicle has enough power reserved to deploy the airbags for 60 seconds. In the case of GM and the vehicles with the switches, the car had up to 150 milliseconds ( 0.15 seconds) of reserved power to sense a crash and deploy the airbags $[7,8]$.

\subsection{Timeline}

To ensure the reader has a full understanding of the background for the ignition switch, below is a timeline of important dates [9-11]. These dates include every time the ignition switch was changed, a change was approved, or test results didn't meet requirements.

- Late 1990's:

- GM creates requirements for ignition switch, including validation requirements and tests

- Ignition switch bid was won by Eaton Corporation

- Early prototypes showed problems with torque requirements. Calvin Wolf and Eaton Corp discuss possible fixes. Wolf is transferred to new job.

- Ray DeGiorgio takes over as lead engineer for ignition switch.

- 2001:

- Delphi acquires Eaton Corporations switch division

- Problem Resolution Tracking System (PRTS) problem arises with torque requirements. Change to initial design approved by DeGiorgio, problem marked as resolved.

- 2002:

- Validation Report shows that torque still does not meet minimum requirements.

- 2004:

- DeGiorgio approves part.

- PRTS problem with Cobalt, key turns when bumped by driver's knee. Possible solutions to fixing problem are discussed; none are approved due to cost.

- 2005:

- July:

- Chevy Cobalt crashes. Airbags didn't deploy, car was in Accessory power mode.

- December:

- GM issues bulletin regarding the ignition switch. Possible solutions include removing heavy items off of keychain and avoiding contact with key.

- DeGiorgio sends change request for ignition switch to Delphi. Delphi sends 24 prototype switches with new design.

- 2006:

- Performance tests show switches still don't meet minimum requirements, however torque is higher than previous years.

- DeGiorgio signs off on new part, doesn't change part number. 
- 2009

- GM opens investigation into crashes caused by the ignition switches. This leads to total redesign of ignition key for 2010 models.

- 2014

- GM announces recall.

\section{THE PROBLEM}

The problem with the ignition switch recall isn't the switch itself, but how it was allowed to go into production in the first place. The evidence is apparent that the part did not meet requirements, even after the initial design was changed. So how did it get approved for production? Lack of understanding by GM engineers on how the car was built seems to be a major factor. Other factors include:

- Multiple problems around ignition switch: On top of the torque issues, the ignition switch also had electrical problems that prevented it from starting cars in cold conditions. Comparing the two problems, it is easy to see how the torque issue was pushed aside.

- Convenience, not safety: Soon after the vehicles with the faulty ignition switches were released, dealerships started receiving complaints about moving stalls. When the first reports came in about the switches, technicians working on the vehicles were rarely able to replicate the issue. Since the car was still drivable afterwards, this caused the switch to be marked as a convenience, not safety, issue.

- Cost a problem:Many changes to a vehicle are rejected because the cost is too high. Usually those changes are for convenience, not for safety reasons. In 2005, GM engineers had a meeting to discuss possible fixes to the switch. These fixes included increasing the torque and adding a detent to the lock housing. Unfortunately, this meeting occurred during the early stages of GM fighting bankruptcy. Since GM was considering the ignition switch problem a matter of personal convenience, the cost to fix the switches wasn't justifiable, so the solutions were ignored [12-15].

\section{WHO SHOULD BE RESPONSIBLE}

There are many questions surrounding the aftermath of the recall. Many include who should be blamed for the recalls. Should the entire company be at fault, or just the individuals responsible for the part? What about the manufacturer? Some even push the blame past both purchaser and part supplier to the individual material suppliers. While many fingers are being pointed at many different people, it boils down to two responsible parties: GM and Delphi.

\subsection{GM}

General Motors, as a whole, holds the most responsibility for the faulty switch. Their inadequate process, careless engineers and promotion of ignorance are just some of the reasons why they failed on this part.

a) Process: While the approval of the switch was done by one engineer, it was GM's process that allowed them to be the only engineer needed to approve such an important part. Again, in 2006, it was one engineer that approved a change to that part that would go unnoticed for years thanks to GM's process. It all seems to come down to the atmosphere. When this part was being built, it was just before GM filed for bankruptcy. They had the 
attitude of going as cheap as possible whenever possible. That's not the attitude to have when building anything that requires attention.

b) Careless engineers: Since the recalls started rolling out earlier this year, $15 \mathrm{GM}$ employees have been fired $[16,17]$ that were involved with the switch; fifteen employees that prevented the switch from being fixed. Why? They attribute it to cost, but the cost is minimal compared to cost GM is paying now. The real answer: because they were careless. They didn't understand the part to begin with and didn't take the time to do so. They just kept classifying it as a convenience issue. Even after non-GM people had made the connection between the switch and the airbags. Even after investigative reports from the fatal crashes came back with the ignition in accessory and the airbags not deployed. When a non-GM employee can connect the dots faster than an engineer who was responsible for the part can, then there's obviously something wrong.

c) Ignorance: As stated previously, there were numerous attempts to fix the switch after the part was released. GM demonstrated ignorance when it failed to fix the problem years earlier. It wasn't because they didn't have the means to; it was because no one wanted to be responsible. They all wanted to remain ignorant of the fact that it was a faulty switch, so that they wouldn't be in the position they are now. Clearly, that didn't work for a lot of people.

\subsection{Delphi}

Delphi, the part supplier for the switch, is guilty of two things:

a) They tested and delivered a part with known errors: During Delphi's PPAP Production Part Approval Process - for the ignition switch, they had noted multiple times that the ignition switch did not meet GM's minimum torque requirements. However, in the event that a purchaser approves a product that has known errors, Delphi is obligated, per their contract, to deliver those products. Such was the case with the GM ignition switch. While GM deserves the bulk of the blame, Delphi is still responsible for the part itself and the fact that it didn't meet requirements to begin with.

Delphi is also responsible for extending the initial validation plan and performing additional tests that may have been necessary, which they did not do. Some examples of additional tests will be introduced in the following section.

b) They remade the part without changing the part number: While this was primarily GM's decision, Delphi should have known better, and noted in their systems that the part was changed.

It was unlucky for Delphi to be a part of this recall. As a supplier, you are responsible for delivering a quality product. In times where the product does not meet the standards of the purchaser after it has been built to exact specifications, then it is up to the supplier to work with the purchaser to get the product fixed. This can cost time and money, sometimes more than what the purchaser is willing to pay.

\section{SOLVING THE PROBLEM}

At this point, the problem with the GM switch has been identified, and the blame has been distributed amongst GM and Delphi. While that's fine and dandy, it doesn't give much to go on for them to approve in the future. This section provides suggestions on where GM could have improved during this dark time, focusing on cost and process, which seem to be to two main culprits. 


\subsection{Cost}

One of the main reasons the ignition switch wasn't fixed was due to cost. Table 1 shows a cost comparison on fixing the switch before production versus fixing the switch after a recall. The total cost for fixing the switch after a recall does not include future lawsuits and legal fees.

As is apparent in Table 1, the difference in cost is extreme; so much that GM could have fixed the ignition switch 100 times during production before meeting the total cost of fixing it after. To paint an even broader picture, $\$ 26$ million is less than one percent of GM's current yearly earnings [18]. While this may seem like a lot, GM should, from this point, remember that a recall costs more money than fixing a problem to begin with.

Table 1: Difference in cost during production and after recall.

\begin{tabular}{lll}
\hline Cost & During Production (US\$) & After Recall (US\$) \\
\hline & & 700 million (recalling and repairing [19]) \\
Fixing & 26 million & +35 million (NHTSA fine [18]) \\
$\begin{array}{l}\text { Ignition } \\
\text { switch }\end{array}$ & $(10$ for 2.6 million vehicles $[15])$ & +600 million (compensation fund [20]) \\
& & +1.3 billion (civil lawsuits legal fees $[19])$ \\
Total: & $\mathbf{2 6}$ million & $\mathbf{2 . 6 3 5}$ billion \\
\hline
\end{tabular}

\subsection{Process}

The purpose of a process is to keep the project on schedule, provide specific project requirements, and offer validation methods so that the right product is built. Many of these points were not accomplished with the process GM used while building the ignition switch.

a) Lack of understanding: While building a vehicle, it is important for the engineers responsible to understand how the vehicle works when it's put together. That includes knowing how components work on their own as well as with other modules. The fact that GM engineers did not understand how the ignition switch affected other components, like the airbags and power steering, conveys the message that the requirements were not clear, or the engineers just didn't care. Those are both unacceptable during a project.

To solve this problem, GM should make it a point that every person on a project understands the project itself, and individual parts of the project. This includes understanding the requirements fully.

b) Validation: The whole validation plan for this part was unsuccessful. Tests that were failing were marked as approved. There was no test coverage for real-world examples, and clearly there were no integration tests around the ignition switch and other modules.

To improve, GM should provide better test coverage at the beginning of the project instead of relying on the supplier to do so. Such tests should include real-world and integration tests. An example of a real-world test, especially for this situation, would be testing weighted key chains. A large number of people - teenage girls in particular - have extra items on their key chains: house keys, reward cards, and tiny stuffed animals. It is not unusual for a key chain to have added weight. This should be at the top of the list of things to test for a vehicles ignition switch. 
c) Approval: The big question on this is why was only one man responsible for the switch? Better yet, why was it acceptable for one man to sign-off on something so significant to a vehicle? GM can improve their approval process by adding more people to look over the requirements, design and test results to ensure that the product is right.

d) Unwilling to take responsibility: After the initial release, there were many opportunities to fix the switch. There were many meetings to discuss possible options, but each meeting resulted in the rumored "GM Nod" - where executives nod in agreement but nothing gets done after the meeting ends. This is where GM's mindset needs to change the most. In the event of a change, someone needs to take responsibility to make sure it is fixed. The switch is an example of what happens when no one is willing to take responsibility.

\subsection{Requirements}

Another solution to the problem would be to make sure that the current requirements are met to begin with, or change the requirements to remove the problem entirely. For example, prevent the key from turning out of Run while the vehicle is in Drive. Or, rearrange the initial layout of the states so that Run is at $90^{\circ}$ instead of Accessory. If those are illogical or out of reach, add detents to the switch to help hold the ignition in place.

\section{CONCLUSION}

The purpose of this paper was to shed light on the current GM recalls. Many people, including the authors, have wondered how such an event could have occurred and taken so long to resolve. It is obvious that lack of understanding and initiative is to blame. The recall could have been prevented if GM had made it a top priority of identifying and understanding requirements from the start.

Lack of understanding from a vehicle's engineers and company overall is unacceptable when it comes to the safety of people. It was negligence that caused the part to be approved and carelessness that kept the problem hidden for so long. The cost of their recklessness: over a dozen lives and countless injuries. It would have been cheaper for GM to fix the problem in the first place.

\section{REFERENCES}

[1] General Motors (2014) GM Ignition Switch Update. http://www.gmignitionupdate.com

[2] Benavides M.C. (2014) NHTSA Notification Campaign No. 14V-047. http://www.odi.nhtsa.dot.gov/acms/cs/jaxrs/download/doc/UCM450663/RCDNN-14V047$\underline{3409 . p d f}$

[3] Fletcher M, Mufson S (2014) Why Did GM Take So Long to Respond to Deadly Defect? Corporate Culture May Hold Answer. http://www.washingtonpost.com/business/economy/why-did-gm-take-so-long-to-respondto-deadly-defect-corporate-culture-may-hold-answer/2014/03/30/5c366f6c-b691-11e3-b84e897d3d12b816_story.html

[4] Svoboda T, General Motors (2000) Analysis Development/Validation Plan \& Report (ADVP\&R) for Suppliers: DeltaZ Ignition Switch.

http://democrats.energycommerce.house.gov/sites/default/files/documents/GM-AnalysisValidation-Report-Torque-2002-5-21.pdf

[5] Waxman H, DeGette D, Schakowsky J (2014) Democrats Request Details about GM Approval of Faulty Ignition Switches. http://democrats.energycommerce.house.gov/index.php?q=news/democrats-request-detailsabout-gm-approval-of-faulty-ignition-switches 
[6] DeGiorgio R (2001) Component Technical Specification. http://democrats.energycommerce.house.gov/sites/default/files/documents/GM-ComponentTechnical-Specification.pdf.

[7] Valukas A. (2014) Report to Board of Directors of General Motors Company Regarding Ignition Switch Recalls. http://www.scribd.com/doc/228310223/GM-s-Valukas-SwitchRecall-Report

[8] Durbin D.(2014) GM Recall Shows How Airbags Don't Always Work. http://www.usatoday.com/story/money/cars/2014/05/13/gm-recall-airbags-complex-and-alldifferent /9048515/

[9] Energy and Commerce Committee (2014) The GM Ignition Switch Recall: Investigation update.

http://energycommerce.house.gov/hearing/the-gm-ignition-switch-recallinvestigation-update

[10] Gutierrez G, Gardella R, Reynolds T. (2014) GM Report: Engineer Approved 'Switch From Hell' Even Though It Didn’t Meet Specs. http://www.nbcnews.com/storyline/gm-recall/gm-report-engineer-approved-switch-helleven-though-it-didnt-n123791

[11] Committee on Energy and Commerce Democrats (2014) General Motors Ignition Switch Investigation: Key Documents from April 1, 2014 Hearing. http://democrats.energycommerce.house.gov/index.php?q=page/general-motors-ignitionswitch-investigation-key-documents-from-april-1-2014-hearing

[12] Korinek D (2005) GM PRTS N172404.

http://democrats.energycommerce.house.gov/sites/default/files/documents/GM-PRTSChevrolet-Cobalt-October-2004.pdf

[13] Arturo A. (2006) Email Regarding Delta Ignition Samples with New PCB/Plunger. http://democrats.energycommerce.house.gov/sites/default/files/documents/Email-DelphiEmployees-2006-1-9.pdf

[14] Rodriquez E. (2006) General Motors Commodity Validation Sign-off for Delta Ignition Switch. http://democrats.energycommerce.house.gov/sites/default/files/documents/General-MotorsCommodity-Validation-Sign-off-Delta-Ignition-Switch-4-26-2006.pdf

[15] Mendoza F. (2006) Test Report for Updated Ignition Switches. http://democrats.energycommerce.house.gov/sites/default/files/documents/Delphi-TestReport-2006-1-25.pdf

[16] Committee Majority Staff (2014) Email Regarding Hearing on "The GM Ignition Switch: Why Did It Take So Long?" http://www.safetyresearch.net/Library/House_Committee_Majority_Staff_Report 3-302014-3.pdf

[17] Higgins T, Plungis J. (2014) Barra Confidante Still at GM Was in Ignition-Flaw Debate. http://www.bloomberg.com/news/2014-06-26/gm-documents-show-engineer-went-againstcompany-panel.html

[18] Isidore C, Marsh R (2014) GM to Pay \$35 Million Over Delayed Recall. http://money.cnn.com/2014/05/16/news/companies/gm-nhtsa

[19] Bennet J. (2014) GM Holders Seek Recall Cost Estimate. http://online.wsj.com/articles/gm-holders-look-for-estimate-of-cost-of-recall-suits1402356884

[20] Geier B. (2014) General Motors Compensation Fund Now Open for Business. http://fortune.com/2014/08/01/gm-compensation-program-now-open-for-business 